International

Medical Society

http://imedicalsociety.org

\title{
Construction and Validation of Digital Application for Teaching Vital Signs
}

\begin{abstract}
Francisco Gilberto Fernandes Pereira1, Luciana Maria Oliveira de Sousa ${ }^{2}$, Débora Valente da Silva ${ }^{3}$, Natasha Marques Frota ${ }^{4}$, Joselany Áfio Caetano ${ }^{5}$
\end{abstract}

\section{Abstract}

Objective: To describe the stages of construction and validation of a digital application for teaching vital signs for nursing.

Methods: It is a methodological development study, conducted between 2014 and 2015, following the standard steps of Galvis-Panqueva: construction [analysis, design and development); and validation (evaluation), which occurred through the measurement of the Content Validity Index (CVI), according to opinion of experts nurses and computer analysts.

Results: The Vitaleasy entitled application was developed with intuitive interface, available for download on Android systems, contemplating the vital signs: pain, temperature, respiratory rate, heart rate and blood pressure, as well as one quiz tab test. As for the validation of appearance and content, the application had global CVI 0.8.

Conclusions: It is concluded that the application is a feature that presents viable characteristics for use in teaching vital signs for nursing students.

\section{Introduction}

Post-secondary education in Brazil has been through restructures ranging from the admission form of student in university courses, the pedagogical strategies of construction of knowledge and teachinglearning process [1].

In the latter case, the most recent challenges require professors to have a posture that maximizes the critical and reflective capacity of
1 Nurse. Masters degree in Nursing. Federal University of Piauí.

2 Nursing Student. University of Fortaleza.

3 Nursing Student. Estácio of Ceará University Center.

4 Nurse. Doctorade degree in Nursign. Estácio of Ceará University Center.

5 Nurse. Doctorade degree in Nursing. Federal University of Ceará.

\section{Contact information:}

\section{Francisco Gilberto Fernandes Pereira}

Address: Rua Professor Vicente Silveira, 100, Bl. 2, ap 404. Bairro: Vila União, Fortaleza-Ceará. Zip code: 60410-322 Tel: +55 (85) 996837423

$\equiv$ gilberto.fp@hotmail.com

\section{Keywords}

Vital signs; Nursing education; Validation studies; Technology. 
the student, and through the internalization of technology in teaching spaces, to transform the practice of teaching and learning in a more collaborative, playful, dynamic and contemporary activity.

In undergraduate courses of health area, progress has been significant in this regard, such as: the creation of the Virtual Man that provides learning of forms and functions of the human body in a three dimension language; the strengthening of Telemedicine and telehealth; and the multimedia platforms of distance learning [2].

Specifically in nursing, it has been increasing the development and use of Information and Communication Technologies (ICTS), setting in a contemporary teaching mechanism, which privileges the process of automation, also being useful to enhance security in the process of making a care decision [3].

The most recurrent themes have been those dealing with sexual and reproductive health [4], evaluation and treatment of wounds [5], nursing management [6] and basic procedures of the profession [7], which were developed in an Virtual Learning Environment (VLE) of hypermedia type, in order to provide through virtual interaction means to facilitate the implementation of tasks in nursing.

The idealization of this study originated from the perception that during the first contact of the undergraduate student with the specific universe of nursing, there is a difficulty in learning the new typical coding of health, especially regarding semiotics, highlighting the most basic and fundamental actions that is checking vital signs.

Studies confirm that the moment of learning the action of checking the vital signs is permeated with joy for the new discovery and because the students feel more identified with the profession, but also by fear and insecurity about the correct way to check, interpret the findings and give them specific nomenclature $[8,9]$.

Thus, it is highlighted the importance of developing a multimedia resource, the application type for mobile devices that offers the undergraduate student a way of a quick consult, easily transported to various practices scenarios in health facilities. Therefore, it is understood that by accessing this type of platform, the student will be able to address some questions with more autonomy, will feel safer to perform the semiotics of checking vital signs and also could understand better what this result means in terms of clinical outcome for the patient.

The realization of this research is by the need of rehabilitation of the forms of education in the health area, allowing the academic a more interactive form of study, in addition to being a prerogative currently adopted by universities in order to support the classroom teaching.

The objective of the study was to describe the stages of construction and validation of a digital application for teaching vital signs for nursing.

\section{Methods}

It is a methodological research which purpose includes the stages of development, evaluation and improvement of technological products and processes [10], that in the case of this study has the creation of the application as a teaching strategy of vital signs for nursing students.

The period of the study was from March 2014 to May 2015, and all the steps for the operationalization of the research occurred according the theoretical framework of Galvis-Panqueva due to its cohesion with the aims and objectives of the research. Thus, the phases of this research are: construction [analysis, design and development); and validation (evaluation) [11].

For the analysis stage survey was conducted, along with students and nursing professors of the locus institution of research, about topics that needed more profitable approach and that could be worked in this technological aspect. Its was opted for the theme of vital signs due to the demand 
presented as for the difficulties that students reported in memorizing reference values and their clinical implications. At this stage, they defined the objectives, target audience, content and technology infrastructure.

In relation to the drawing was established the instructional design, navigation structure, in this case in the form of application with free download for Android platform and the interface, to ensure interaction, autonomy and facility in all commands. The development, which is the effective step of execution, was carried out by a software engineer with the supervision of researchers.

The next phase was the validation of the appearance and content. For this step were contacted expertise in nursing education and in educational technologies to validate the content, and experts in the software development area for validation of appearance. The sample was composed by 22 evaluators, 11 nurses and 11 computer analysts, whom were identified from searching at the Lattes Platform, and contacted via email. It was opted for a unpaired number formation of specialists in each area following the recommendation of other studies that used this method $[12,13]$.

The inclusion criterion was to achieve three points according to the following items: for nurses - doctorate degree in nursing (4 points), professors with master's degree in nursing education (3 points), development of technologies in nursing education (2 points), nursing professor (1 point); and for computer analysts - doctorate degree in computer science and having developed software (4 points), master's degree in computer science and having developed software (3 points), graduated in computer science and having developed software (2 points), graduated in computer technology area (1 point).

At the time, were sent the link to experts to download the application and an evaluation form with questions concerning the adequacy of the proposal, objectives, organization, layout, writing, ap- pearance, and motivation for educational material. The answers were presented in Likert scale ranging from 1 (not adequate) to 5 (adequate for excellence).

After receiving of all the forms, responses were transferred to a database in SPSS and organized in tables with demonstration of absolute frequency and measurement of CVI (Content Validity Index), considering as approved item when it is greater than 0.78, according to the medical literature for validation studies with more than six experts [14].

The study was submitted to the Ethics Committee of the Federal University of Ceará, which approved its fulfillment through document No. 983,129. All participants signed up the consent form, and they were guarded by the bioethical principles contained in the National Health Council Resolution 466/12 [15].

\section{Results}

\section{Construction of the application VitalEasy}

It was developed six topics that enables the student intuitive interaction with the application: temperature, respiratory rate (breathing), blood pressure, heart rate (pulse), and pain. In addition, a tab titled Test was also created, using the quiz kind of strategy that will serve as a method for assessing student knowledge gained on the issues. For each topic, except for the Test, were included four modules: concept, measurement, reference values and the technique to perform the procedure.

Each functionality related to measurement of the vital signs was coded with numeric intervals of physiological normality and abnormality, and associated with their respective terminology according to the semiotic language. Thus, the student chooses the vital sign to be observed, enter the values found and the application will show the appropriate terminology for the situation (Figure 1). 
Figure 1: Access screens to blood pressure and POP tabs. Fortaleza, Brazil, 2016. Fortaleza, Brazil, 2016.

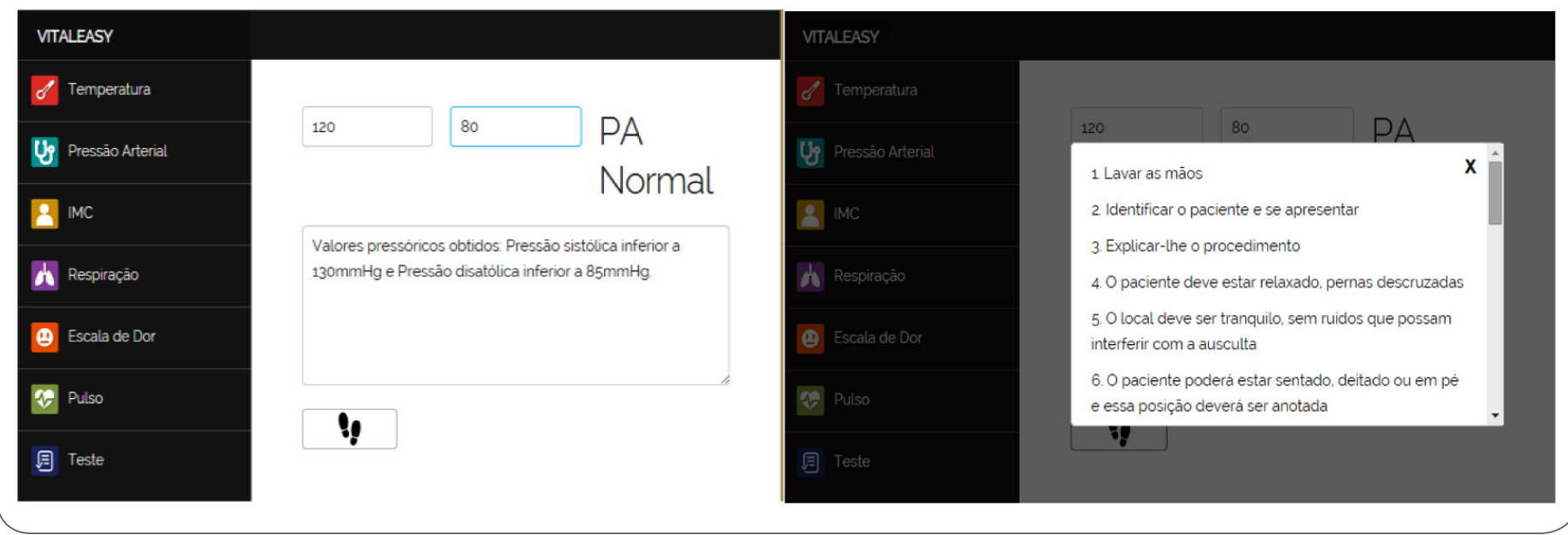

Figure 2: Test tab access screens. Fortaleza, CE, 2016.

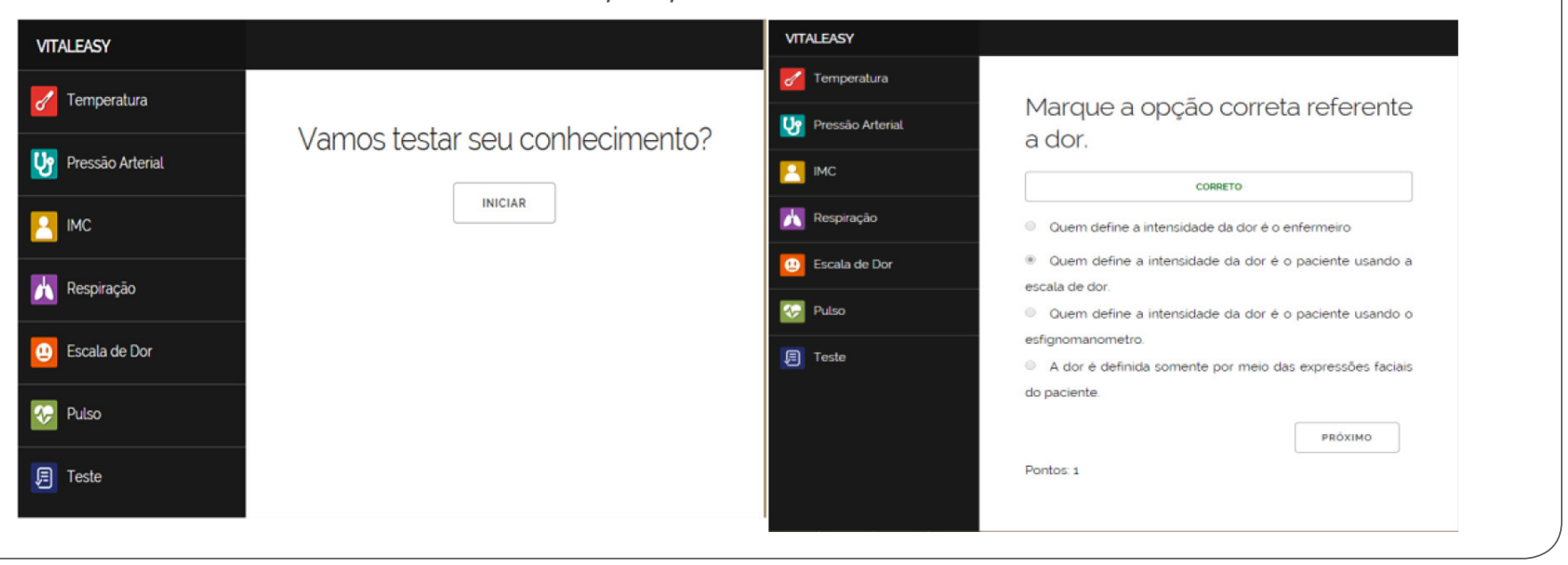

As for the pain parameter, it was used the visual analog scale in association with the numerical scale, in wich according to the value completed by the student, will be the adequacy of the facial expression automatically.

Also for each of the items was made one Standard Operating Procedure (SOP), based on a literature review, to lead the student in the realization of the procedure, so they can solve possible doubts about the semiotics verification of that specific type of vital sign, and therefore to provide greater security for the execution step by step (Figure 1).

In the Test tab (Figure 2), the student will answer objective questions with multiple alternatives about topics such as terminology, reference values, semiotics, equipment used and professional attitu- de, so that will help them to identify their greatest difficulties and so they can study focusing on their needs

\section{Validation with specialists}

Of the eleven experts from the nursing field that evaluated the application, seven were doctors and four masters, and all acted as teachers in superior education. The scores ranged from three to five, according to the criteria in the selection presented previously.

Table 1 shows the distribution of evaluations performed by nurse specialists with questions concerning the adequacy of the proposal, objectives, organization, layout, writing, appearance, and motivation for educational material. 
Table 1. Distribution of the number of nursing specialists according validation criteria - Fortaleza, CE, 2016.

Item

\section{Validation}

\begin{tabular}{|c|c|c|c|c|c|c|c|}
\hline \multirow{2}{*}{\multicolumn{2}{|c|}{ Item }} & \multirow{3}{*}{$\begin{array}{c}\mathrm{Al} \\
-\end{array}$} & \multirow{3}{*}{$\begin{array}{c}\text { SA } \\
-\end{array}$} & \multirow{3}{*}{$\begin{array}{c}\text { PA } \\
1\end{array}$} & \multirow{3}{*}{ A } & \multirow{3}{*}{$\mathrm{AE}$} & \multirow{3}{*}{$\begin{array}{c}C V I^{*} \\
0.9\end{array}$} \\
\hline & & & & & & & \\
\hline 1. & The application is appropriate for the proposal that is intended & & & & & & \\
\hline 2. & $\begin{array}{l}\text { The application allows you to generate valid results when it comes } \\
\text { to dynamic and effective teaching }\end{array}$ & - & - & - & 5 & 6 & 1.0 \\
\hline 3. & $\begin{array}{l}\text { The application facilitates learning of the concepts used and their } \\
\text { applications }\end{array}$ & - & - & - & 6 & 5 & 1.0 \\
\hline 4. & The application provides help in a complete way & - & 1 & 3 & 3 & 4 & 0.6 \\
\hline 5. & It provides help in a not tiring way & - & - & - & 1 & 10 & 1.0 \\
\hline 6. & $\begin{array}{l}\text { The application content corresponds the content present in } \\
\text { nursing literatures }\end{array}$ & - & - & - & 3 & 8 & 0.8 \\
\hline 7. & The application is attractive for nursing students & - & - & 1 & 3 & 7 & 0.9 \\
\hline
\end{tabular}

Table 2. Distribution of number of experts from the Information Technology area according to validation criteria - Fortaleza, CE, 2016.

\begin{tabular}{|c|c|c|c|c|c|c|c|}
\hline \multirow{2}{*}{\multicolumn{2}{|c|}{ Item }} & \multicolumn{6}{|c|}{ Validation } \\
\hline & & $\mathrm{Al}$ & SA & PA & A & $\mathrm{AE}$ & $C V I^{*}$ \\
\hline 1. & The download of the application is easily accomplished & - & - & - & 1 & 10 & 1.0 \\
\hline 2. & The language used in the application is easy to understand & - & - & 2 & 5 & 4 & 0.8 \\
\hline 3. & The resources used in the application are properly used & - & - & 2 & 7 & 2 & 0.8 \\
\hline 4. & The resources used in the application are used comprehensively & - & - & 1 & 8 & 2 & 0.9 \\
\hline 5. & The application interface is attractive & - & 0 & 3 & 5 & 3 & 0.7 \\
\hline 6. & The application provides help in a clear way & - & 1 & 4 & 3 & 3 & 0.5 \\
\hline 7. & The application is easy to handle & - & - & 1 & 6 & 4 & 0.9 \\
\hline 8. & It provides help in a not tiring way & - & - & 1 & 2 & 8 & 0.9 \\
\hline
\end{tabular}

Al: Absolutely Inappropriate; SA: Slightly Appropriate; PA: Partially Appropriate; A: Appropriate; AE: Appropriate for Excellence.

*: Content Validity Index

Most items were evaluated by the experts and reaching $C V I$ superior than 0.78 , in other words, not requiring further adjustment. The ones that stand out with best score were: the dynamics, facility of learning concepts and help in a not tiring way, with $C V I=1.0$ each.

As for the topic 4, more than half of the experts assessed the application as out the standard appropriate for excellence, resulting in $\mathrm{CVI}=0.6$. This analysis required changes in educational technology, which were inserted more scientific information on vital signs, as well as improved the questions Test tab.
About the specialists on the area of information technology, three were masters and only eight graduated, however, all had the requirement of the development of a software. The scores ranged from three to four according to pre-established criteria.

According to data presented in Table 2 the best rated item identified was that the download of the application is easily accomplished with $C V I=1.0$. As for the topics on the attractiveness of the interface and clarity of information, they did not achieve scores of more than half of the experts as appropriate for excellence, with only three points each, and CVI 0.7 and 0.5 , respectively. 
Finally, it was performed the global CVI of the application to ensure the overall validation as for the appearance and content. According to the evaluation of nurses overall the CVI was approximately 0.9 , and for computer specialists was 0.8 , thus confirming that the application is a feature that presents viable characteristics for use in teaching vital signs for nursing students.

\section{Discussion}

The nursing education in Brazil has been growing with the various educational resources available to build the teaching-learning process, such as the use of technologies for the practical improvement in the academic scenario and nursing care.

The expectation of students in regard to the inclusion of educational technologies in learning at university is a reality more and more present in the educational scenario, since the information is complete, especially in relation to practical application, with the provision of detailed videos for the implementation of procedure and digital applications to clear doubts outside the classroom [16].

The literature pointed out two studies that showed relation of vital signs with the use of educational technology in nursing education, which are the digital learning objects [17] and digital educational technology [18]. However it was felt the need to provide guidance to a digital application, in wich the student can handle such technology for Android.

As for nursing researches for the use of mobile devices we can highlight the mobile application on vaccination in Brazil from updated data from the National Immunization Program of the Ministry of Health [19], and other mobile application for patient classification and evaluation of nursing workload in intensive care, the Nursing Activities Score (NAS) [20, 21]. Both applications are in the final development phase and subsequent evaluation of the software in clinical practice, with the purpose of updating the nursing professional and greater integration of mobile technology in their work environments.

One of the main advantages of mobile applications is the breakdown of the mobility limitation, since they can follow their users 24 hours a day wherever they are. Another important aspect is the personality that the equipment provides to its users, considering that the professional can use your personal device, with which you are already accustomed to dealing daily.

The use of technological tools in health care is becoming increasingly widespread, because this kind of support gives professionals greater speed and accuracy. With regard to nursing care in Brazil, the adoption of technological resources is a growing fact since the late 60's, with the scientific basis of the profession. Mobile computing can be applied to various areas within the field of health. Among these applications we can highlight remote monitoring, diagnostic support and support for decision-making [21, 22].

The adoption of mobile devices by nursing students and nurses has increased, ranging from 45 to $85 \%$ so that the contents of these devices has achieved enough popularity [16].

The use of mobile application aims to improve academic and professional performance, support the decision and represent a resource that optimizes the care and evaluation process, in order to assume the information is adequate and updated on the care point of view, and also has best conditions to choose and take decision $[23,24]$.

In a study performed with elementary school students whom evaluated motivational aspects of an online educational material, revealed high satisfaction and indicated the organization of teaching resource as an essential variable to the motivation and learning of users [25].

In this sense, the use of educational technologies has been driven by a number of advantages to facilitate the understanding of a studied content [16], respect the time of student learning [26] as well 
as to allow the students to train as many times as necessary in order to facilitate learning.

In a research developed in the United States has identified a total of 83 mobile applications documented in the literature. Of these, 57 were aimed at health professionals and the issue most found was the assistance to medical diagnosis. There was also 11 applications aimed at medical students and nursing and 15 for patients [27].

The development of research-related mobile applications should be examined and tested by professionals who know the real needs of users. In order to recognize the needs of these users is essential to plan and implement new technologies in a consistent and appropriate manner, according to the specific demands, tested in research and implemented in in care practice [28].

Thus, after making the construction of VitalEasy application it was observed the the need to submit such technology to the validation process along with nursing field experts to assess the adequacy of the proposal, objectives, organization, layout, writing, appearance, and motivation for educational material, as well as computer experts to evaluate the facility to download the application, interface attractiveness and clarity of the information, did not reach scores. It is pertinent to validate in order to improve the points considered important and to predict possible difficulties that students can submit with the application use.

Another important aspect presented in VitaIEasy is the use of a quiz type of strategy that will serve as support for the student to assess their knowledge after using the application. Studies in Australia and in Slovenia show that the application of tests followed by the use of technological resources functions as an alternative to stimulate students' interest in building their own knowledge $[29,30]$.

The nursing education is challenged to prepare new professionals with competence, skill and attitude to practice in a complex, emerging and techno- logically sophisticated environment. However, one should not only increase the production of digital materials, but the critical appropriation possibilities of them and overcoming the limits, beyond those that classroom teaching can offer [16]. Faced with this reality, it is necessary not only the construction of a technological product, but also becoming indispensable the use of it to the population to which it is intended.

\section{Conclusion}

The VitalEasy application presents design features, interactivity, usability, interface, scientific concepts and attractiveness that have been well evaluated by experts, making it validated for the use in teaching for undergraduate nursing students.

It is a limitation of this study, not performing the validation stage with the students, as to execute this step, it would be necessary to validate the technological construct with experts from the field of nursing and information technology.

Thus, it is suggested that the application is widespread for the use in various undergraduate courses in nursing, and that a link is created in the application itself so that users may be able to evaluate the construct, which will serve as a basis for its final validation.

\section{References}

1. Mancebo D, Vale AA, Martins TB. Políticas de expansão da educação superior no Brasil 1995-2010. Rev. Bras. Educação. 2015; 20 (60): 31-51. Doi: 10.1590/\$1413-24782015206003.

2. Prado C, Silva IA, Soares AVN, Aragaki IMM, Shimoda GT, Zaniboni VF, et al. Nursing contribuitons to the development of the Brazilian Telehealth Lactation Support Program. Rev Esc Enferm USP. 2013; 47 (4): 986-91. Doi: 10.1590/S008062342013000400031

3. Fernández-Alemán JL, García ABS, Montesinos MJL, MarquésSánchez P, Darkistade EB, Rivera FJP. Exploring the use of information and communication technologies and social networks among university nursing faculty staff. An opinion survey. Invest Educ Enferm. 2014; 32 (3): 438-50. Doi: 10.1590/ S0120-53072014000300009. 
4. Holanda VR, Pinheiro AKB. Desenvolvimento de um sistema hipermídia para o ensino interativo das doenças sexualmente transmissíveis. Rev. Enferm. UFPE on line. 2015; 9 (supl. 2): 781 9. Doi: 10.5205/reuol.6391-62431-2-ED.0902supl201502.

5. Camacho ACLF, Tenório DM, Silva RP, Barreto BMF, Oliveira $B G R B$. Evaluation of the interactive blog on wound repair and nursing care. Rev. Pesqui. Cuid. Fundam. 2013; 5 (3): 202-10. Doi: 10.9789/2175-5361.2013.v5i3.202-210.

6. Pereira MCA, Melo MRAC, Silva ASB, Évora YDM. Evaluation of a Webquest on the theme "managment of material resources in nursing" by undregraduate students. Rev. LatinoAm. Enfermagem. 2010; 18 (6): 1107-14. Doi: 10.1590/S010411692010000600010.

7. Frota NM, Barros LM, Araújo TM, Caldini LN, Nascimento JC, Caetano JÁ. Construção de uma tecnologia educacional para o ensino de enfermagem sobre punção venosa periférica. Rev. Gaúcha Enferm. 2013; 34 (2): 29-36. Doi: 10.1590/S198314472013000200004

8. McNelis AM, Ironside PM, Ebright PR, Dreifuerst KT, Zvonar SE, Conner SC. Learning nursing practice: a multisite, multimethod investigation of clinical education. Journal of Nursing Regulation. 2014; 4 (4): 30-5. Doi: 10.1016/S2155-8256(15)30115-0.

9. Yuan HB, Williams BA, Man CY. Nursing students' clinical judgment in high-fidelity simulation based learning: A quasiexperimental study. Journal of Nursing Education and Pratice. 2014; 4(5): 7. Doi: 105430/jnep.v4n5p7.

10. Tarone EE, Gass SM, Cohen AD. Research methodology in second-language acquisition. New York: Routlegde; 2013.

11. Galvis-Panqueva A, Mendoza P. Ambientes virtuales de aprendizaje: uma metodologia para su creación. Informática Educ. 1999; 12 (2): 295-17.

12. Teles LMR, Oliveira AS, Campos FC, Lima TM, Costa CC, Gomes LFS, et al . Construção e validação de manual educativo para acompanhantes durante o trabalho de parto e parto. Rev Esc Enferm USP. 2014; 48 (6): 977-84. Doi: 10.1590/S0080623420140000700003

13. Freitas LV, Teles LMR, Lima TM, Vieira NFC, Barbosa RCM, Pinheiro $A K B$, et al. Physical examination during prenatal care: construction and validation of educational hypermedia for nursing. Acta Paul Enferm. 2012; 25 (4): 581-8. Doi: 10.1590/ S0103-21002012000400016.

14. Alexandre NMC, Coluci MZO. Content validity in the development and adaptation processes of measurement instruments. Ciênc. Saúde Coletiva. 2011; 16 (7): 3061-8. Doi: 10.1590/S1413-81232011000800006
15. Brasil. Resolução n.466, de 12 de dezembro de 2012. Aprova normas regulamentadoras de pesquisas envolvendo seres humanos. Brasília: Diário Oficial da União; 2012.

16. Free C, Phillips G, Felix L, Galli L, Patel V, Edwards P. The effectiveness of M-health technologies for improving health and health services: a systematic review protocol. BMC Res Notes. 2010; 3 (250): 1-7. Doi: 10.1186/1756-0500-3-250.

17. Cogo ALP, Silveira DT, Pedro ENR, Tanaka RY, Catalan VM. Aprendizagem de sinais vitais utilizando objetos educacionais digitais: opinião de estudantes de enfermagem. Rev Gaúcha Enferm. 2010; 31 (3): 435-41. Doi: 10.1590/S198314472010000300005.

18. Góes FSN, Camargo RAA, Fonseca LMM, Oliveira GF, Hara CYN, Felipe $H R$, et al. Avaliação de tecnologia digital educacional "sinais vitais e anatomia" por estudantes da educação profissionalizante em enfermagem. Rev Min Enferm. 2015; 19 (2): 37-43. Doi: 10.5935/1415-2762.20150024.

19. Oliveira TR, Costa FMR. Desenvolvimento de aplicativo móvel de referência sobre vacinação no Brasil. J Health Inform. 2012; 4 (1): 23-7. http://www.jhi-sbis.saude.ws/ojs-jhi/index.php/jhisbis/article/view/161/109. Accssed Apr 1, 2016.

20. Silveira DT, Catalan VM, Neutzling AL, Martinato MLH, Borges GC M. Sistema nursing activities score: etapas de desenvolvimento de um sistema móvel para enfermagem. J Health Inform. 2010; 2 (2): 44-50. http://www.jhi-sbis.saude.ws/ojs-jhi/index.php/jhisbis/article/view/96/57. Accssed Apr 1, 2016.

21. Catalan VM, Silveira DT, Neutzling AL, Martinato LHM, Borges GCM. Sistema NAS: Nursing Activities Score em tecnologia móvel. Rev Esc Enferm USP. 2011; 45 (6): 1419-26. Doi: 10.1590/ S0080-62342011000600020

22. Menezes Júnior JV, D'Castro RJ, Rodrigues FMM, Gusmão CMG, Lyra NRS, Sarinho SW. InteliMed: uma experiência de desenvolvimento de sistema móvel de suporte ao diagnóstico médico. Rev Bras Comp Aplic. 2011; 3 (1): 30-42. http://www. upf.br/seer/index.php/rbca/article/view/1316. Accssed Apr 1, 2016.

23. Marin HF. Sistemas de Informação em saúde: considerações gerais. J Health Inform. 2010;2(1):20-4. http://www.jhi-sbis. saude.ws/ojs-jhi/index.php/jhi-sbis/article/viewFile/4/52. Accssed Apr 1, 2016.

24. Grossi LM, Pisa IT, Marin HF. Oncoaudit: desenvolvimento e avaliação de aplicativo para enfermeiros auditores. Acta Paul Enferm. 2014; 27 (2): 179-85. Doi: 10.1590/19820194201400031.

25. Picolini MM, Maximino LP. Programa de educação em síndromes genéticas: avaliação motivacional de um material educacional online. Rev CEFAC. 2014; 16 (1): 252-9. Doi: 10.1590/1982021620149812. 
26. Holanda VR, Pinheiro AKB, Pagliuca LMF. Aprendizagem na educação online: análise de conceito. Rev Bras Enferm. 2013; 66 (3): 406-11. Doi: 10.1590/S0034-71672013000300016.

27. Mosa ASM, Yoo I, Sheets L. A systematic review of healthcare applications for smartphones. BMC. 2012; 12 (67): 14-21. Doi: 10.1186/1472-6947-12-67.

28. Tibes CMS, Dias JD, Zem-Mascarenhas SH. Aplicativos móveis desenvolvidos para a área da saúde no Brasil: revisão integrativa da literatura. Rev Min Enferm. 2014; 18 (2): 471-8. Doi: 10.5935/1415-2762.20140035.

29. Trobec I, Starcic Al. Developing nursing ethical competences online versus in the traditional classroom. Nursing Ethics. 2015; 22 (3); 352-66. Doi: 10.1177/0969733014533241.

30. Mardegan KJ, Schofield MJ, Murphy GC. Comparison of an interactive CD-based and traditional instructor-led Basic Life Support skills training for nurses. Aust Crit Care. 2014; 28 (3): 160-7. Doi: 10.1016/j.aucc.2014.06.001.

Publish in International Archives of Medicine

International Archives of Medicine is an open access journal publishing articles encompassing all aspects of medical science and clinical practice. IAM is considered a megajournal with independent sections on all areas of medicine. IAM is a really international journal with authors and board members from all around the world. The journal is widely indexed and classified Q1 in category Medicine. 